Article

\title{
Impact of Grape Products on Lipid Profile: A Meta-Analysis of Randomized Controlled Studies
}

\author{
Roberta Lupoli ${ }^{1, *,+}{ }^{+}$, Paola Ciciola ${ }^{2,+}{ }^{\dagger}$, Giuseppina Costabile ${ }^{2}$, Rosalba Giacco ${ }^{3}$, \\ Matteo Nicola Dario Di Minno ${ }^{4}$ and Brunella Capaldo ${ }^{2}$ (D) \\ 1 Department of Molecular Medicine and Medical Biotechnology, Federico II University, 80131 Naples, Italy \\ 2 Department of Clinical Medicine and Surgery, Federico II University, 80131 Naples, Italy; \\ paola.ciciola@gmail.com (P.C.); giukost@libero.it (G.C.); bcapaldo@unina.it (B.C.) \\ 3 Institute of Food Science, National Research Council, 83100 Avellino, Italy; rgiacco@isa.cnr.it \\ 4 Department of Translational Medical Sciences, Federico II University, 80131 Naples, Italy; \\ dario.diminno@hotmail.it \\ * Correspondence: roby.lupoli@gmail.com; Tel./Fax: +39-0817462302 \\ + The two Authors equally contributed to this study.
}

Received: 16 December 2019; Accepted: 20 January 2020; Published: 22 January 2020

\begin{abstract}
Background: Growing evidence shows that grape polyphenols can improve cardiovascular risk factors. Although there are clear data supporting a beneficial effect of grape supplementation on blood pressure and glucose metabolism, the effects of grape polyphenols on lipid metabolism are still controversial. Objective: We performed a meta-analysis of randomized controlled trials (RCTs) to assess the effect of grape products on lipid profile. Design: A systematic search was performed in the PubMed, Web of Science, Scopus, and EMBASE databases without any language or publication year restriction. The reference lists of all retrieved articles were manually reviewed. RCTs evaluating the impact of grape products/juice/extracts on lipid profile were included. Difference in total cholesterol (TC), high-density lipoprotein cholesterol (HDL-C), low-density lipoprotein cholesterol (LDL-C), triglycerides (TG), oxidized low-density lipoprotein cholesterol (oxLDL-C), apolipoprotein (apo) A, apo B before and after administration of grape products or placebo were expressed as mean differences (MD) with pertinent 95\% confidence intervals (95\% CI). The impact of clinical and demographic features on effect size was assessed by meta-regression. Results: The administration of grape products is associated with a significant improvement of lipid profile, as evidenced by changes in TC (MD: $-7.6 \mathrm{mg} / \mathrm{dL}$ (-0.2 mmol/L); 95\% CI: -10.8, -4.4; $p<0.001)$, HDL-C (MD: $1.4 \mathrm{mg} / \mathrm{dL}$ (0.04 mmol/L); 95\% CI: $\left.0.8,1.9 ; p<0.001, \mathrm{I}^{2}=74.7 \%, p<0.001\right), \mathrm{LDL}-\mathrm{C}(-6.3 \mathrm{mg} / \mathrm{dL}(-0.16 \mathrm{mmol} / \mathrm{L}) ; 95 \% \mathrm{CI}:-9.5,-3.0$; $p<0.001$ ), oxLDL-C (MD: $-4.5 \mathrm{U} / \mathrm{L} ; 95 \% \mathrm{CI}:-7.5,-1.5 ; p=0.003, \mathrm{I}^{2}=90.6 \%, p<0.001$ ), apo B (MD: $-2.4 \mathrm{mg} / \mathrm{dL}(-0.05 \mu \mathrm{mol} / \mathrm{L}) ; 95 \% \mathrm{CI}:-4.5,-0.3 ; p=0.026)$, and TG (MD: $-14.5 \mathrm{mg} / \mathrm{dL}(-0.16 \mathrm{mmol} / \mathrm{L})$; $95 \%$ CI: $-17.7,-11.2 ; p<0.001)$ levels in subjects receiving grape products compared to placebo. With regard to the extent of the lipid-lowering effect, compared to baseline values, the highest reduction was reported for LDL-C (MD: $-5.6 \mathrm{mg} / \mathrm{dL}(-0.14 \mathrm{mmol} / \mathrm{L}) ; 95 \% \mathrm{CI}:-9.5,-1.7 ; p=0.005)$ and for oxLDL-C (MD: $\left.-5.0 \mathrm{U} / \mathrm{L} ; 95 \% \mathrm{CI}:-8.8,-1.2 ; p=0.010, \mathrm{I}^{2}=0 \%, p=0.470\right)$. Conclusions: Grape polyphenols exert a favorable effect on lipid profile in humans by significantly reducing plasma levels of LDL-C and oxLDL-C.
\end{abstract}

Keywords: grape; polyphenol; lipid profile; meta-analysis 


\section{Introduction}

Polyphenols are a heterogeneous class of bioactive compounds mainly found in plant-based foods, such as fruits, vegetables, wholegrain cereals, and beverages, such as coffee, tea, and red wine. According to their chemical structure, five main classes of polyphenols have been identified: flavonoids, phenolic acids, lignans, stilbenes, and other minor polyphenols [1].

There is much evidence that polyphenol-rich food consumption is associated with several health benefits, namely reduction of the risk of type 2 diabetes, obesity, and cardiovascular (CV) diseases [2-5]. Of note, some classes of plant-derived polyphenols have obtained specific health claims by the European Food Safety Authority (EFSA), such as the hydroxytyrosol and its derivatives contained in extra virgin olive oil for their proven anti-oxidant action [6], and the cocoa flavanols for their favorable effect on endothelium-dependent vasodilation [7]. Over the last years, growing attention has been paid to polyphenols from grape for their potential to reduce CV risk [8,9]. Indeed, grape and its fractions (skin, flesh/pulp, seeds) contain flavonoids, resveratrol, and phenolic acids [10] to a variable extent, depending on grape's species and geographic origin [11,12].

The cardioprotective effects of grape polyphenols are likely mediated by their ability to improve CV risk factors [13-15], to reduce oxidative stress [16,17] and inflammatory status [18,19], to increase the anti-oxidant capacity $[18,20]$, and to inhibit platelet function [21,22]. In healthy subjects, grape consumption has been shown to improve flow-mediated dilation and to blunt the endothelial dysfunction caused by a high-fat diet [23]. In individuals with components of the metabolic syndrome, randomized placebo-controlled trials have shown that grape supplementation for a variable time (2-24 weeks) - provided in the form of powder, juice, or seed extracts-improved several metabolic abnormalities, significantly lowered blood pressure [24-26], and reduced oxidative stress markers, i.e., oxidized LDL [27]. With regard to glucose metabolism, a recent meta-analysis by Zhu et al. evaluating nine clinical trials performed in patients with type 2 diabetes mellitus (DM2) demonstrated the efficacy of resveratrol in reducing fasting glucose and improving insulin sensitivity with no relevant effect on glycated hemoglobin [28]. Similar benefits on glucose metabolism were observed after consumption of different grape products, such as seed extracts [29], juice [30], and pomace [31-33]. In contrast, the effects of grape polyphenols on lipid metabolism are less clear [34,35], with some studies demonstrating a significant lipid-lowering effect [20,36,37] and others failing to find any change in lipid profile [38-40]. Therefore, we conducted a meta-analysis of intervention cohort studies to assess the effect of grape products on lipid profile, i.e., total cholesterol (TC), high-density lipoprotein cholesterol (HDL-C), low-density lipoprotein cholesterol (LDL-C), triglycerides (TG), and main apolipoprotein (Apo) concentrations taking into account some possible confounders.

\section{Materials and Methods}

A protocol for this review was prospectively developed, reporting the specific objectives, the criteria for study selection, the outcomes, and the statistical methods.

\subsection{Search Strategy}

To identify all available studies, a systematic research of the literature published until June 2019 pertaining to the effect of grape products on lipid fractions was performed according to PRISMA (Preferred Reporting Items for Systematic reviews and Meta-Analyses) guidelines. The research was carried out in the electronic databases (PubMed, Web of Science, Scopus, and EMBASE), using the following search terms in all possible combinations: grape, lipid, cholesterol, total cholesterol, HDL cholesterol, LDL cholesterol, triglycerides, oxidized-LDL cholesterol, apolipoprotein A, and apolipoprotein B.

The search strategy was developed without any language or publication year restriction. In addition, the references of all retrieved articles were manually reviewed to find other relevant articles. In the case of missing data, study authors were contacted by e-mail to try to retrieve original data. 
Two authors (P.C. and G.C.) independently analyzed each article and performed the data extraction independently. In case of disagreement, a third investigator was consulted (R.L.). Discrepancies were resolved by consensus. Selection results showed a high inter-reader agreement $(\kappa=0.98)$ and have been reported according to the PRISMA flowchart (Figure S1).

\subsection{Data Extraction and Quality Assessment}

According to the pre-specified protocol, RCT studies evaluating the impact of supplementation with grape juice/extracts/products on lipid profile were included. Case-reports, case-series without a control group, reviews, and animal studies were excluded. We included in the analysis RCT studies which provide values (mean and standard deviation/standard error) of at least one variable among TC, HDL cholesterol, LDL cholesterol, triglycerides, oxidized-LDL cholesterol (oxLDL-C), apolipoprotein A (apo A), and apolipoprotein B (apo B) before and after administration of grape juice/extracts/products or placebo. In each study, data regarding sample size, major clinical and demographic characteristics of the study population, variables of interest in the intervention and placebo groups were extracted before and after grape supplement administration.

\subsection{Statistical Analysis and Risk of Bias Assessment}

Statistical analysis was carried out using Review Manager (Version 5.2, The Cochrane Collaboration, Copenhagen, Denmark) provided by the Cochrane Collaboration. Differences in changes in lipid parameters between intervention and placebo groups as well as lipid changes before and after grape supplementation were expressed as mean difference (MD) with pertinent $95 \%$ confidence intervals (95\% CI) for continuous variables. TC, HDL-C, LDL-C, TG were expressed in milligrams/deciliter $(\mathrm{mg} / \mathrm{dL})$, apo A and apo B in grams/liter (g/L), oxLDL-C in U/L.

The overall effect was tested using $Z$ scores and significance was set at $p<0.05$. Statistical heterogeneity between studies was assessed with chi square Cochran's $Q$ test and with $\mathrm{I}^{2}$ statistic, which measure the inconsistency across study results and describe the proportion of total variation in study estimates, that is due to heterogeneity rather than sampling error. In detail, $\mathrm{I}^{2}$ values of $0 \%$ indicates no heterogeneity, $25 \%$ low, $25-50 \%$ moderate, and 50\% high heterogeneity [41]. Publication bias was assessed by the Egger's test and represented graphically by funnel plots of the standard difference in means versus the standard error. Visual inspection of funnel plot asymmetry was performed to address for possible small-study effect, and Egger's test was used to assess publication bias, over and above any subjective evaluation. A $p<0.10$ was considered statistically significant [42]. In the case of a significant publication bias, the Duval and Tweedie's trim and fill method with the random-effect model was used to allow for the estimation of an adjusted effect size [43]. In order to be as conservative as possible, the random-effect method was used for all analyses to take into account the variability among included studies. 


\subsection{Subgroup Analyses}

Differences in changes in lipid parameters in the grape supplementation group were stratified according to $(a)$ the type of grape product; $(b)$ the polyphenol content of supplementation; $(c)$ duration of polyphenol supplementation.

\subsection{Meta Regression Analyses}

To assess whether differences among included studies could be affected by demographic variables (mean age, male gender), coexistence of traditional CV risk factors (diabetes mellitus, obesity, hyperlipidemia), and length of follow-up, we performed meta-regression analyses after implementing a regression model with difference in TC, HDL-C, LDL-C, and TG as dependent variables $(y)$ and the above-mentioned co-variates as independent variables $(x)$. No meta-regression analysis was performed with apo A, apo B, and oxLDL-C because of the limited number of studies reporting clinical and demographic data. This analysis was performed with Comprehensive Meta-analysis (Version 2, Biostat, Englewood, NJ, USA (2005)).

\section{Results}

After excluding duplicates, the search retrieved 699 articles. Of these studies, 655 were excluded because after scanning the title and/or the abstract they were off the topic or were reviews/comments/case reports or lacked data of interest. Twenty studies were excluded after full-length paper evaluation. One study [44] provided separate data on pre- and postmenopausal women and was considered as two separate datasets. Three studies $[27,45,46]$ reported separate data on two intervention groups receiving different amount of grape product compared with a single placebo group. In order to avoid duplicating controls, we considered data on patients receiving the highest amount of grape product.

Thus, 24 articles ( 25 datasets, 618 subjects assigned to grape juice/extract/product administration and 587 subjects assigned to placebo) were included in the final analysis [27,29,32-35,44-61]. In detail, 21 studies (22 data-sets) reported data on TC, 22 studies (23 datasets) on HDL-C, 20 studies (21 datasets) on TG, 20 studies ( 21 datasets) on LDL-C, 4 studies ( 4 datasets) on oxLDL-C, 2 studies ( 2 datasets) on apo A, 3 studies (3 datasets) on apo B.

\subsection{Study Characteristics}

All included studies were RCTs; the major characteristics of study populations are shown in Table 1. The number of enrolled subjects varied from 8 to 50, the mean age from 20.7 to 62.0 years, and the prevalence of male gender from $0 \%$ to $100 \%$. 
Table 1. Characteristics of included studies.

\begin{tabular}{|c|c|c|c|c|c|c|c|c|}
\hline Author & Study Design & $\begin{array}{l}\text { Population } \\
(n)\end{array}$ & $\begin{array}{l}\text { Follow-up } \\
\text { (weeks) }\end{array}$ & $\begin{array}{l}\text { Type of Grape } \\
\text { Product }\end{array}$ & Type of Control & Reported Outcomes & $\begin{array}{c}\text { Age } \\
\text { (years) }\end{array}$ & $\begin{array}{c}\text { Male Gender } \\
\text { (\%) }\end{array}$ \\
\hline $\begin{array}{c}\text { Argani } \\
2016[47]\end{array}$ & $\begin{array}{l}\text { RCT-parallel } \\
\text { double-blind }\end{array}$ & $\begin{array}{c}70 \\
\text { mild to moderate } \\
\text { hyperlipidemia }\end{array}$ & 8 & SE & placebo & $\begin{array}{l}\text { TC, HDL-C, TG, } \\
\text { LDL-C, apo A }\end{array}$ & 47.0 & 32.7 \\
\hline $\begin{array}{c}\text { Banini } \\
2006[48]\end{array}$ & $\begin{array}{l}\text { RCT-parallel } \\
\text { open }\end{array}$ & $\begin{array}{c}23 \\
\mathrm{~T} 2 \mathrm{DM}\end{array}$ & 4 & $\mathrm{~J}$ & no supplement & $\begin{array}{l}\text { TC, HDL-C, TG, } \\
\text { LDL-C }\end{array}$ & 53.9 & 47.6 \\
\hline $\begin{array}{l}\text { Dohadwala } \\
2010[49]\end{array}$ & $\begin{array}{l}\text { RCT-crossover } \\
\text { double-blind }\end{array}$ & $\begin{array}{c}64 \\
\text { preHT/stage } 1 \mathrm{HT}\end{array}$ & 8 & $\mathrm{~J}$ & placebo & $\begin{array}{l}\text { TC, HDL-C, TG, } \\
\text { LDL-C }\end{array}$ & 42.6 & 68.8 \\
\hline $\begin{array}{c}\text { Hansen } \\
2005[51]\end{array}$ & $\begin{array}{l}\text { RCT-parallel } \\
\text { double-blind }\end{array}$ & $\begin{array}{c}35 \\
\text { healthy subjects }\end{array}$ & 4 & WG & placebo & $\begin{array}{l}\text { TC, HDL-C, TG, } \\
\text { LDL-C }\end{array}$ & 52.0 & 45.6 \\
\hline $\begin{array}{c}\text { Hollis } \\
2009[52] \\
\end{array}$ & $\begin{array}{l}\text { RCT-parallel } \\
\text { open }\end{array}$ & $\begin{array}{c}50 \\
\text { healthy subjects }\end{array}$ & 12 & $\mathrm{~J}$ & no supplement & $\begin{array}{l}\text { TC, HDL-C, TG, } \\
\text { LDL-C }\end{array}$ & 25.0 & NA \\
\hline $\begin{array}{l}\text { Jiménez } \\
2008 \text { [53] }\end{array}$ & $\begin{array}{l}\text { RCT-parallel } \\
\text { open }\end{array}$ & $\begin{array}{c}43 \\
\text { non-smokers }\end{array}$ & 16 & WG & no supplement & $\begin{array}{l}\text { TC, HDL-C, TG, } \\
\text { LDL-C }\end{array}$ & 35.3 & 37.2 \\
\hline $\begin{array}{c}\text { Kar } \\
2009[29]\end{array}$ & $\begin{array}{l}\text { RCT-crossover } \\
\text { double-blind }\end{array}$ & $\begin{array}{c}32 \\
\mathrm{~T} 2 \mathrm{DM} \\
\end{array}$ & 4 & SE & placebo & TC, HDL-C, TG & 62.0 & 50.0 \\
\hline $\begin{array}{c}\text { Martínez-Maqueda } \\
2018 \text { [33] }\end{array}$ & $\begin{array}{l}\text { RCT-crossover } \\
\text { open }\end{array}$ & $\begin{array}{c}98 \\
\text { subjects with MetS ** }\end{array}$ & 6 & WG & no supplement & $\begin{array}{l}\text { TC, HDL-C, TG, } \\
\text { LDL-C }\end{array}$ & 42.6 & 55.1 \\
\hline $\begin{array}{l}\text { Mellen } \\
2010[54]\end{array}$ & $\begin{array}{l}\text { RCT-crossover } \\
\text { double-blind }\end{array}$ & $\begin{array}{c}50 \\
\text { subjects with CAD or } \geq 1 \\
\text { CV risk factor }\end{array}$ & 4 & SE & placebo & $\begin{array}{l}\text { TC, HDL-C, TG, } \\
\text { LDL-C }\end{array}$ & 52.1 & 50.0 \\
\hline $\begin{array}{c}\text { Millar } \\
2018 \text { [55] }\end{array}$ & $\begin{array}{l}\text { RCT-crossover } \\
\text { double-blind }\end{array}$ & $\begin{array}{c}40 \\
\text { subjects with MetS }\end{array}$ & 4 & WG & placebo & TC, HDL-C, TG & 53.5 & 60 \\
\hline $\begin{array}{c}\text { Park } \\
2009[56]\end{array}$ & $\begin{array}{l}\text { RCT-parallel } \\
\text { double-blind }\end{array}$ & $\begin{array}{c}40 \\
\text { healthy subjects }\end{array}$ & 8 & $\mathrm{~J}$ & placebo & $\begin{array}{l}\text { TC, HDL-C, TG, } \\
\text { LDL-C }\end{array}$ & 44.4 & 100.0 \\
\hline $\begin{array}{c}\text { Preuss } \\
2000[35]\end{array}$ & $\begin{array}{l}\text { RCT-parallel } \\
\text { double-blind }\end{array}$ & $\begin{array}{c}19 \\
\text { subjects with } \\
\text { hyperlipidemia }\end{array}$ & 8 & SE & placebo & TC, HDL-C, LDL-C & NA & NA \\
\hline
\end{tabular}


Table 1. Cont

\begin{tabular}{|c|c|c|c|c|c|c|c|c|}
\hline Author & Study Design & $\begin{array}{l}\text { Population } \\
(n)\end{array}$ & $\begin{array}{c}\text { Follow-up } \\
\text { (weeks) }\end{array}$ & $\begin{array}{c}\text { Type of Grape } \\
\text { Product }\end{array}$ & Type of Control & Reported Outcomes & $\begin{array}{c}\text { Age } \\
\text { (years) }\end{array}$ & $\begin{array}{l}\text { Male Gender } \\
(\%)\end{array}$ \\
\hline $\begin{array}{c}\text { Sano } \\
2007[46]\end{array}$ & $\begin{array}{l}\text { RCT-parallel } \\
\text { single-blind }\end{array}$ & $\begin{array}{c}35 \\
\text { subjects with } \\
\text { hyperlipidemia }\end{array}$ & 12 & SE & placebo & $\begin{array}{c}\text { TC, HDL-C, TG, } \\
\text { LDL-C, apo A, apo B }\end{array}$ & 53 & 47.5 \\
\hline $\begin{array}{c}\text { Siasos } \\
2013[57]\end{array}$ & $\begin{array}{l}\text { RCT-crossover } \\
\text { double-blind }\end{array}$ & $\begin{array}{c}26 \\
\text { healthy smokers }\end{array}$ & 2 & $\mathrm{~J}$ & placebo & TC, LDL-C & 26.3 & 38.5 \\
\hline $\begin{array}{c}\text { Sivaprakasapillai } \\
2009[27]\end{array}$ & $\begin{array}{l}\text { RCT-parallel } \\
\text { double-blind }\end{array}$ & $\begin{array}{c}18 \\
\text { subjects with MetS }\end{array}$ & 4 & SE & placebo & $\begin{array}{l}\text { TC, HDL-C, TG, } \\
\text { LDL-C, oxLDL-C }\end{array}$ & 46.5 & 38.5 \\
\hline $\begin{array}{l}\text { Tomé-Carneiro } \\
2012 \text { [59] }\end{array}$ & $\begin{array}{l}\text { RCT-parallel } \\
\text { triple-blind }\end{array}$ & $\begin{array}{c}50 \\
\text { T2DM or hyperlipidemia } \\
\text { under statins }\end{array}$ & 24 & WG & placebo & $\begin{array}{c}\text { TC, HDL-C, TG, } \\
\text { LDL-C, oxLDL-C, apo } \\
\text { B }\end{array}$ & 59.5 & 54.0 \\
\hline $\begin{array}{l}\text { Urquiaga } \\
2015 \text { [32] }\end{array}$ & $\begin{array}{l}\text { RCT-parallel } \\
\text { open }\end{array}$ & $\begin{array}{c}38 \\
\text { male with MetS * }\end{array}$ & 16 & WG & no supplement & HDL-C, TG & 44.0 & 100.0 \\
\hline $\begin{array}{l}\text { Vaisman } \\
2015[45]\end{array}$ & $\begin{array}{l}\text { RCT-parallel } \\
\text { double blind }\end{array}$ & $\begin{array}{c}32 \\
\text { heterogeneous } \S\end{array}$ & 12 & WG & placebo & $\begin{array}{l}\text { TC, HDL-C, TG, } \\
\text { LDL-C }\end{array}$ & 57.0 & 74.4 \\
\hline $\begin{array}{l}\text { Yubero } \\
2013[60]\end{array}$ & $\begin{array}{l}\text { RCT-parallel } \\
\text { double-blind }\end{array}$ & $\begin{array}{c}60 \\
\text { healthy subjects }\end{array}$ & 8 & SK & placebo & $\begin{array}{l}\text { TC, HDL-C, LDL-C, } \\
\text { oxLDL-C }\end{array}$ & 51.0 & NA \\
\hline $\begin{array}{c}\text { Zern } \\
2005[44]\end{array}$ & $\begin{array}{l}\text { RCT-crossover } \\
\text { single-blind }\end{array}$ & $\begin{array}{c}44 \\
\text { pre-/postmenopausal } \\
\text { women }\end{array}$ & 4 & WG & placebo & $\begin{array}{l}\text { TC, HDL-C, TG, } \\
\text { LDL-C }\end{array}$ & $\begin{array}{c}39.7 \\
\text { (premenopausal) } \\
58.5 \\
\text { (postmenopausal) }\end{array}$ & ) \\
\hline $\begin{array}{l}\text { Zunino } \\
2014[61]\end{array}$ & $\begin{array}{l}\text { RCT-crossover } \\
\text { double-blind }\end{array}$ & $\begin{array}{c}24 \\
\text { obese }\end{array}$ & 3 & WG & placebo & $\begin{array}{l}\text { HDL-C, TG, LDL-C, } \\
\text { oxLDL-C }\end{array}$ & 36.0 & 33.3 \\
\hline
\end{tabular}


Eleven studies evaluated the effect of whole grape products (grape powder or pomace) $[32-34,44,45,50,51,53,55,59,61]$, five studies focused on grape juice $[48,49,52,56,57]$, seven studies on grape seed extracts $[27,29,35,46,47,54,58]$, and one study on the effect of grape skin extracts [60].

The presence of dyslipidemia was reported in $0-100 \%$ of patients, diabetes mellitus in $0-100 \%$ of patients, hypertension in $0-86 \%$, smoking habit in $0-100 \%$ and previous coronary artery disease (CAD) in $0-24 \%$. Mean body mass index (BMI) varied from 21.4 to $36.8 \mathrm{~kg} / \mathrm{m}^{2}$ (mean $28.4 \mathrm{~kg} / \mathrm{m}^{2}$ ) and waist circumference from 84.1 to $109 \mathrm{~cm}$. Mean fasting glucose levels ranged from 80 to $103 \mathrm{mg} / \mathrm{dL}$, systolic blood pressure from 113 to $134 \mathrm{mmHg}$ and diastolic blood pressure from 70 to $94 \mathrm{mmHg}$.

\subsection{Total Cholesterol, HDL Cholesterol, Triglycerides}

As reported in Figure S2, we found a greater reduction in TC levels after administration of grape products as compared with placebo (MD: $-7.6 \mathrm{mg} / \mathrm{dl}(-0.2 \mathrm{mmol} / \mathrm{L}) ; 95 \% \mathrm{CI}:-10.8,-4.4 ; p<0.001)$. Heterogeneity among studies was significant $\left(\mathrm{I}^{2}=94.3 \%, p<0.001\right)$ and no reduction in the overall heterogeneity was found after excluding one study at a time. In the intervention group, we found a trend toward a significant decrease in TC levels after supplementation with grape products as compared with pre-intervention TC levels (MD: $-5.0 \mathrm{mg} / \mathrm{dL}(-0.13 \mathrm{mmol} / \mathrm{L}) ; 95 \% \mathrm{CI}:-10.2,0.1$; $p=0.057, \mathrm{I}^{2}=41.9 \%, p=0.021$ ).

Although administration of grape products resulted in a more significant increase in HDL-C levels as compared with placebo (MD: $1.4 \mathrm{mg} / \mathrm{dL}(0.04 \mathrm{mmol} / \mathrm{L}) ; 95 \%$ CI: $0.8,1.9 ; p<0.001, \mathrm{I}^{2}=74.7 \%$, $p<0.001$, Figure S3), no significant change in HDL-C was found in the intervention group between preand post-supplementation levels (MD: $0.9 \mathrm{mg} / \mathrm{dL}(0.02 \mathrm{mmol} / \mathrm{L}) ; 95 \% \mathrm{CI}:-0.3,2.1 ; p=0.122, \mathrm{I}^{2}=0 \%$, $p=1.000)$.

We observed a greater decrease in TG levels after supplementation with grape products as compared with placebo (MD: $-14.5 \mathrm{mg} / \mathrm{dL}(-0.16 \mathrm{mmol} / \mathrm{L}) ; 95 \% \mathrm{CI}:-17.7,-11.2 ; p<0.001$, Figure S4). Heterogeneity among these studies was significant $\left(\mathrm{I}^{2}=94.1 \%, p<0.001\right)$ and no reduction in the overall heterogeneity was found after excluding one study at a time. However, we found no significant changes in TG levels between pre- and post-supplementation in the intervention group (MD: $0.60 \mathrm{mg} / \mathrm{dL}$ (0.01 mmol/L); $95 \%$ CI: $\left.-2.0,3.2 ; p=0.654, \mathrm{I}^{2}=0 \%, p=0.881\right)$.

Meta-regression models (Table S1) showed that an increasing age was associated with a less significant improvement in HDL-C after grape product supplementation as compared with placebo (Z-value: $-2.58, p=0.001$ ). None of the other clinical and demographic variables influenced differences in changes in TC, HDL-C, and TG.

\subsection{LDL Cholesterol}

A significantly greater reduction in LDL-C levels was observed after administration of grape products as compared with those after the administration of placebo (MD: $-6.3 \mathrm{mg} / \mathrm{dL}(-0.16 \mathrm{mmol} / \mathrm{L})$; 95\% CI: $-9.5,-3.0 ; p<0.001$ ) (Figure 1 ). Heterogeneity among studies was significant $\left(\mathrm{I}^{2}=96.3 \%\right.$, $p<0.001)$ and no reduction in the overall heterogeneity was found after excluding one study at a time. 


Study name
Argani 2016
Banini 2006
Dohadwala 2010
Hansen 2005
Hollis 2009
Jiménez 2008
Martinez-Maqueda 2018
Mellen 2010
Park 2009
Preuss 2000
Sano 2007
Siasos 2013
Sivaprakasapillai 2009
Taghizadeh 2016
Tomé-Carneiro 2012
Vaisman 2015
Vigna 2003
Yubero 2013
Zern 2005 (a)
Zern 2005 (b)
Zunino 2014

\begin{tabular}{rrrr}
\multicolumn{5}{c}{ Statistics for each study } \\
$\begin{array}{rrrr}\text { Difference } \\
\text { in means }\end{array}$ & $\begin{array}{c}\text { Lower } \\
\text { limit }\end{array}$ & \multicolumn{1}{c}{ Upper } & \\
& limit & p-Value \\
$-26,100$ & $-28,563$ & $-23,637$ & 0.000 \\
$-6,900$ & $-13,139$ & $-0,661$ & 0.030 \\
$-3,000$ & $-5,296$ & $-0,704$ & 0.010 \\
$-3,000$ & $-13,767$ & 7,767 & 0.585 \\
$-3,000$ & $-5,762$ & $-0,238$ & 0,033 \\
$-10,400$ & $-16,193$ & $-4,607$ & 0.000 \\
$-3,000$ & $-4,104$ & $-1,896$ & 0.000 \\
$-4,300$ & $-6,532$ & $-2,068$ & 0.000 \\
$-4,100$ & $-11,831$ & 3,631 & 0.299 \\
$-2,000$ & $-6,525$ & 2,525 & 0.386 \\
0,000 & $-3,755$ & 3,755 & 1.000 \\
$-1,000$ & $-5,993$ & 3,993 & 0.695 \\
$-3,000$ & $-4,848$ & $-1,152$ & 0.001 \\
$-3,800$ & $-7,650$ & 0,050 & 0.053 \\
$-1,300$ & $-4,286$ & 1,686 & 0.393 \\
$-5,100$ & $-8,757$ & $-1,443$ & 0.006 \\
$-4,000$ & $-6,999$ & $-1,001$ & 0.009 \\
$-21,560$ & $-23,783$ & $-19,337$ & 0.000 \\
$-12,000$ & $-16,181$ & $-7,819$ & 0.000 \\
$-4,000$ & $-7,228$ & $-0,772$ & 0.015 \\
$-7,940$ & $-10,951$ & $-4,929$ & 0.000 \\
$-6,254$ & $-9,515$ & $-2,994$ & 0.000
\end{tabular}

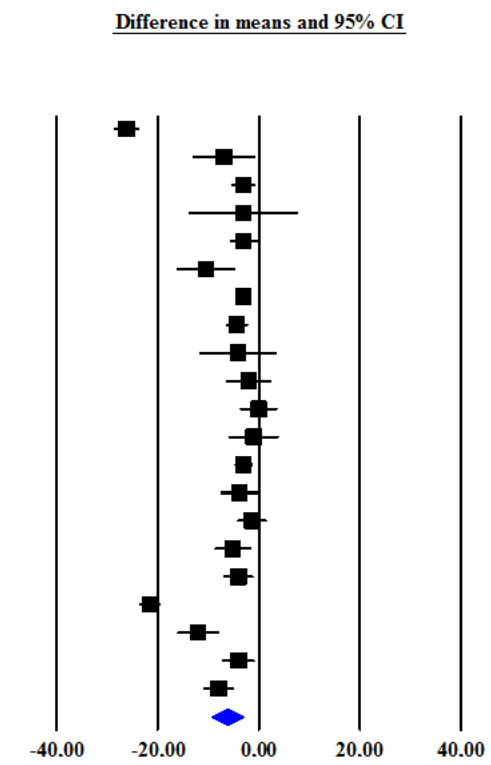

Figure 1. Changes in low-density lipoprotein cholesterol (LDL-C) levels after administration of grape products as compared with controls.

Meta-regression models (Supplemental Table S1) showed that none of the evaluated clinical and demographic variables influenced differences in changes in LDL-C after grape products supplementation as compared with placebo.

In the intervention group, we found a significant decrease in LDL-C after supplementation with grape products as compared with pre-intervention LDL-C levels (MD: $-5.6 \mathrm{mg} / \mathrm{dL}(-0.14 \mathrm{mmol} / \mathrm{L}$ ); $95 \%$ CI: $-9.5,-1.7 ; p=0.005)$ with a non-significant heterogeneity $\left(\mathrm{I}^{2}=29.1 \%, p=0.105\right)$. Stratifying the population according to grape product types, we found a significant reduction in LDL-C levels in subjects taking whole grape products (MD: $-6.3 \mathrm{mg} / \mathrm{dL}(-0.16 \mathrm{mmol} / \mathrm{L}) ; 95 \% \mathrm{CI}:-11.0,-1.6 ; p=0.009$, $\left.\mathrm{I}^{2}=0 \%, p=0.901\right)$ while no significant difference in LDL-C was found after supplementation with grape seeds extracts (MD: $\left.-4.3 \mathrm{mg} / \mathrm{dL}(-0.11 \mathrm{mmol} / \mathrm{L}) ; 95 \% \mathrm{CI}:-10.9,2.2 ; p=0.193, \mathrm{I}^{2}=28.9 \%, p=0.218\right)$ and with grape juice (MD: $\left.0.21 \mathrm{mg} / \mathrm{dL}(0.01 \mathrm{mmol} / \mathrm{L}) ; 95 \% \mathrm{CI}:-7.6,8.1 ; p=0.957, \mathrm{I}^{2}=0 \%, p=0.948\right)$ (Figure 2). Only one study [60] reported a significant reduction in LDL-C after consumption of grape skin extracts. Moreover, analyzing data according to polyphenol content of the supplements used in each study, we found a significant reduction in LDL-C levels in subject taking supplements with a polyphenol content $>400 \mathrm{mg} /$ day (MD: $-5.8 \mathrm{mg} / \mathrm{dL}(-0.15 \mathrm{mmol} / \mathrm{L}) ; 95 \% \mathrm{CI}:-10.7,-0.8 ; p=0.022$, $\left.\mathrm{I}^{2}=0 \%, p=0.662\right)$, but not in those receiving supplements with a lower polyphenol content (MD: $\left.-4.3 \mathrm{mg} / \mathrm{dL}(-0.11 \mathrm{mmol} / \mathrm{L}) ; 95 \% \mathrm{CI}:-11.9,3.2 ; p=0.260, \mathrm{I}^{2}=57.2 \%, p=0.013\right)$. Both subjects receiving polyphenol supplementation for $<8$ weeks and those treated for $\geq 8$ weeks showed a significant reduction in LDL-C levels compared to control subjects $(-4.7 \mathrm{mg} / \mathrm{dL}(-0.12 \mathrm{mmol} / \mathrm{L}) ; 95 \% \mathrm{CI}:-6.3$, $-3.1 ; p<0.001$ and $-7.4 \mathrm{mg} / \mathrm{dL}(-0.19 \mathrm{mmol} / \mathrm{L}) ; 95 \% \mathrm{CI}:-13.7,-1.1 ; p=0.02)$. 


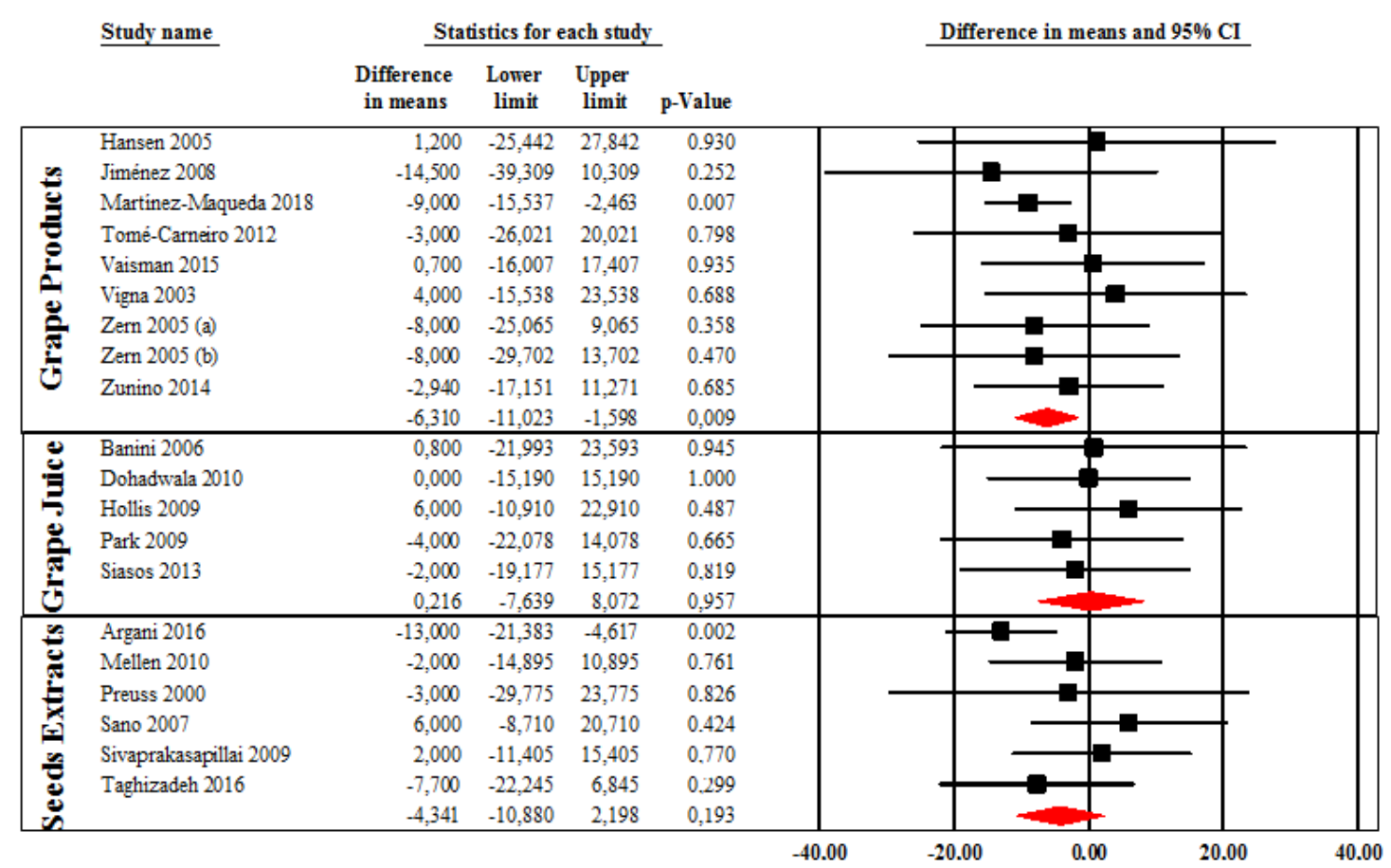

Figure 2. Changes in LDL-C levels in subjects taking whole grape products, grape juice, and grape seeds extracts.

A significantly greater reduction in oxLDL-C levels was observed after administration of grape products as compared with placebo (MD: $-4.5 \mathrm{U} / \mathrm{L} ; 95 \% \mathrm{CI}:-7.5,-1.5 ; p=0.003, \mathrm{I}^{2}=90.6 \%, p<0.001$ ), as well as after supplementation as compared to baseline values (MD: $-5.0 \mathrm{U} / \mathrm{L} ; 95 \% \mathrm{CI}:-8.8,-1.2$; $\left.p=0.010, \mathrm{I}^{2}=0 \%, p=0.470\right)$.

\subsection{Apo A and Apo B}

We found no significant change in apo A levels both considering administration of grape products vs. placebo (MD: $\left.7.7 \mathrm{mg} / \mathrm{dL}(2.8 \mu \mathrm{mol} / \mathrm{L}) ; 95 \% \mathrm{CI}:-7.5,22.9 ; p=0.320 ; \mathrm{I}^{2}=97.7 \%, p<0.001\right)$ and considering pre- vs. post-supplementation levels (MD: $7.1 \mathrm{mg} / \mathrm{dL}(2.5 \mu \mathrm{mol} / \mathrm{L}) ; 95 \% \mathrm{CI}:-0.2,14.4$; $p=0.055 ; \mathrm{I}^{2}=0 \%, p=0.361$.

A significant reduction in apo $B$ levels was found after administration of grape products as compared with placebo (MD: $-2.4 \mathrm{mg} / \mathrm{dL}(-0.05 \mu \mathrm{mol} / \mathrm{L}) ; 95 \% \mathrm{CI}:-4.5,-0.3 ; p=0.026)$ with a non-significant heterogeneity among studies $\left(\mathrm{I}^{2}=62.8, p=0,068\right)$. However, in the intervention group, no significant change in apo $\mathrm{B}$ was found after supplementation with grape products as compared with pre-supplementation levels (MD: $-3.2 \mathrm{mg} / \mathrm{dL}(-0.06 \mu \mathrm{mol} / \mathrm{L}) ; 95 \% \mathrm{CI}:-8.2,1.9 ; p=0.218)$ without heterogeneity among studies $\left(\mathrm{I}^{2}=0 \%, p=0.993\right)$.

\subsection{Publication Bias}

Visual inspection of funnel plots and the Egger's test suggested the absence of publication bias and of small-study effect for studies evaluating TC, HDL-C, and LDL-C (Egger's $p=0.592,0.906$, and 0.761, respectively; Figure S5). In contrast, a significant publication bias was found for studies evaluating TG (Egger's $p=0,018$, Figure S6). The Duval and Tweedie's trim and fill analysis (Supplemental Figure S6) showed that after adjusting for publication bias an even higher difference in TG was confirmed in patients receiving grape supplementation as compared to placebo (MD: $-15.7 \mathrm{mg} / \mathrm{dL}(-0.18 \mathrm{mmol} / \mathrm{L})$, 95\% CI: $-19.0,-12.4)$. 


\section{Discussion}

The results of the present meta-analysis show that the administration of grape products is associated with a significant improvement of lipid profile, as evidenced by changes in TC, HDL-C, LDL-C, oxLDL-C, apo B, and TG levels in subjects receiving grape products compared to placebo. With regard to the extent of the lipid-lowering effect, the reduction was $-5.6 \mathrm{mg} / \mathrm{dL}(-0.14 \mathrm{mmol} / \mathrm{L})$ for LDL-C and $-5.0 \mathrm{U} / \mathrm{L}$ for oxLDL-C. Although the magnitude of the effect is not impressive in absolute terms, it may still be noteworthy for the prevention of $\mathrm{CV}$ diseases on a population basis. Indeed, for each $1 \%$ decrease in LDL-C, there is a $1 \%$ decrease in cardiovascular event rate [62]. Of particular clinical relevance is also the reduction in oxLDL-C-an important player in the atherosclerotic process.

To the best of our knowledge, this is to date the largest meta-analysis evaluating the relationship between grape product intake and lipid profile. In a recent systematic review, Woerdeman et al. concluded that grape polyphenols seemed not to induce any relevant benefit on glycemia, blood pressure, and lipid levels in individuals with or without characteristics of the metabolic syndrome [63]. Differently, in the present study we found a favorable effect of grape supplementation on lipid profile. In addition, the meta-regression analysis showed that the presence of metabolic diseases, such as diabetes, obesity, and dyslipidemia, did not affect the differences in the changes of the lipid fractions, suggesting that the benefits of grape supplementation take place in individuals with or without metabolic diseases.

A critical factor to be considered in examining the currently available literature on grape polyphenols and cardiovascular benefits relates to the dose of grape product supplementations. In fact, the dose is quite variable among the studies analyzed, ranging from 22.4 to $2370 \mathrm{mg} /$ day; thus, it cannot be excluded that in some studies, the dose of grape supplementation was too low to exert measurable effects, which could erroneously lead to the conclusion of negative results. The importance of the dose clearly emerges from our study; in fact, the subgroup analyses show that the reduction in LDL-C reached statistical significance when the daily grape polyphenols supplementation was $>400 \mathrm{mg} /$ day. This finding should be taken into account in supporting clinical recommendations as well as in designing future intervention studies.

The biological mechanisms underlying the favorable impact of grape products on lipid levels remain largely speculative. It is widely recognized that polyphenolic compound can inhibit pancreatic lipase, resulting in reduced fat digestion and absorption, with consequent reduced secretion of triglycerides rich lipoproteins in the hepatocytes [64]. In addition, grape polyphenols could reduce lipoprotein synthesis in hepatocytes by decreasing acyl-Coenzyme A cholesterol acyltransferase, inhibiting microsomal triglyceride transfer protein (MTP), and increasing fatty acid oxidation [65]. In addition, polyphenols could influence LDL-C composition as well as the cholesterol/triglyceride ratio by inhibiting the cholesterol ester transfer protein (CETP) [66]. With regard to the reduction in oxLDL-C, there is evidence that polyphenols are able to prevent LDL oxidation through their radical-trapping effects and their function as hydrogen donors to $\alpha$-tocopherol radicals [67]. Interestingly, Toaldo et al. have recently shown in healthy subjects that the acute consumption of grape juice promoted a significant decrease in thiobarbituric acid reactive substances (TBARS) —an index of lipid peroxidation levels-when compared with the control intervention [68]. In line with this finding, Sano et al. demonstrated a significant reduction in the concentration of oxLDL-C, measured as plasma malondialdehyde after a 12-week administration of grape seed extracts in healthy subjects [46].

This meta-analysis enabled us to evaluate the individual impact of various grape products on lipid profile. As known, phenolic compounds are mainly distributed in the skin, stem, leaf, and seed of the grape, with juice having a lower phenolic content. Furthermore, the types of phenolic compounds vary with cultivar, soil composition, geographic origin, and also in relation to the different parts of the grape; i.e., seeds are rich in gallic acid, $(+)$-catechin, epicatechin, dimeric procyanidin, proanthocyanidins, while the skin is rich in proanthocyanidins, ellagic acid, myricetin, quercetin, kaempferol, trans-resveratrol [69]. In our study, we found a favorable effect of whole grape products on lipid profile, while no significant change was observed after supplementation with grape seed 
extracts and grape juice. This finding could be explained by the fact that whole grape products include skin, pomace, and seeds, which supply a mixture of polyphenol compounds with a potential synergistic effect on lipid metabolism [69]. From a clinical point of view, the results of this study support the nutraceutical-based approach as a useful complement to nutritional and pharmacological therapies to improve lipid profile, as stated in recently published guidelines $[70,71]$. With regard to the lipid-modifying effects of grape products, the present data indicate that a consumption of polyphenols derived from whole grape (i.e., pomace) at a minimum dose of $400 \mathrm{mg} /$ day is required to have a significant reduction in LDL-C and oxLDL-C.

Some potential limitations of our study need to be discussed. First, the studies included in our meta-analysis have different inclusion and exclusion criteria and most subjects had concomitant $\mathrm{CV}$ risk factors. Therefore, we performed meta-regression analyses in order to adjust the results by demographic and clinical variables. In addition, since the meta-analysis was performed on aggregate data and there could be some missing information in each study, the multivariate approach allowed for the adjustment of some, but not all, potential confounders. Thus, we cannot exclude the influence of other factors on the outcomes of interest. Furthermore, the studies analyzed presented some variability in (1) type of supplementation, (2) polyphenol content, (3) study duration, and (4) study design. To limit these sources of variability, we performed subgroup analyses specifically stratifying for type of grape supplementation and polyphenols content. Similarly, we introduced study duration among the meta-regression variables, showing that this parameter had no impact on the results. With regard to the study design, although we included only RCTs, a potential source of bias was represented by the type of placebo used in the various studies since in some of them the control group received a placebo while in others no dummy supplementation was administered. Lastly, no data on the effect of grape supplementation on clinical outcomes are available in the studies included. Several studies indicate that the dietary intake of grape polyphenols is associated with an improvement of endothelial function, suggesting a cardioprotective effect of these compounds [24,72]. However, specific studies evaluating cardiovascular and cerebrovascular outcomes are needed to address this issue.

In conclusion, the present meta-analysis shows that grape polyphenols exert a favorable effect on lipid profile in humans by significantly reducing plasma levels of LDL-C and oxLDL-C. The effect is observed with a daily grape polyphenol supplementation $>400 \mathrm{mg}$ /day provided by whole grape products, but not grape seed extracts or grape juice. The lipid-lowering effect of grape polyphenols seems to occur in healthy subjects as well as in subjects with a range of metabolic abnormalities. Additional trials specifically in patients with dyslipidemia or diabetes mellitus are required to confirm this finding.

Supplementary Materials: The following are available online at http://www.mdpi.com/2077-0383/9/2/313/s1, Figure S1: PRISMA Flow Diagram, Figure S2: Changes in TC levels after administration of grape products as compared with controls, Figure S3: Changes in HDL-C levels after administration of grape products as compared with controls, Figure S4: Changes in TG levels after administration of grape products as compared with control, Figure S5: Funnel plots of effect size versus standard error for studies evaluating levels of TC (panel A), HDL-C (panel B), LDL-C (panel C) levels after administration of grape products or placebo, Figure S6: Funnel plots of effect size versus standard error (panel A) and Duval and Tweedie's trim and fill analysis (panel B) for studies evaluating levels of TG after administration of grape products or placebo, Table S1: Meta-regression analyses for TC, HDL-C, TG and LDL-C.

Author Contributions: R.L. conceived and designed the study, performed statistical analysis, interpreted results, and drafted the manuscript. P.C., G.C., and R.G. acquired data and drafted the manuscript. M.N.D.D.M. performed statistical analysis and drafted the manuscript. B.C. conceived and designed the study, interpreted results, and reviewed/edited the manuscript. P.C. had full access to all data in the study and takes responsibility for the integrity of the original data. All authors have read and agreed to the published version of the manuscript.

Funding: No funding and economic support have been received for this study.

Conflicts of Interest: All authors have no conflict of interest and financial disclosure to report. 


\section{References}

1. Pandey, K.B.; Rizvi, S.I. Plant polyphenols as dietary antioxidants in human health and disease. Oxid. Med. Cell Longev. 2009, 2, 270-278. [CrossRef] [PubMed]

2. Tresserra-Rimbau, A.; Rimm, E.B.; Medina-Remón, A.; Martínez-González, M.A.; de la Torre, R.; Corella, D.; Salas-Salvadó, J.; Gómez-Gracia, E.; Lapetra, J.; Arós, F.; et al. PREDIMED Study Investigators. Inverse association between habitual polyphenol intake and incidence of cardiovascular events in the PREDIMED study. Nutr. Metab. Cardiovasc. Dis. 2014, 24, 639-647. [CrossRef] [PubMed]

3. Liu, Y.J.; Zhan, J.; Liu, X.L.; Wang, Y.; Ji, J.; He, Q.Q. Dietary flavonoids intake and risk of type 2 diabetes: A meta-analysis of prospective cohort studies. Clin. Nutr. 2014, 33, 59-63. [CrossRef] [PubMed]

4. Sosnowska, B.; Penson, P.; Banach, M. The role of nutraceuticals in the prevention of cardiovascular disease. Cardiovasc. Diagn. Ther. 2017, 7, S21-S31. [CrossRef]

5. Sahebkar, A.; Serban, M.C.; Gluba-Brzózka, A.; Mikhailidis, D.P.; Cicero, A.F.; Rysz, J.; Banach, M. Lipid-modifying effects of nutraceuticals: An evidence-based approach. Nutrition 2016, 32, 1179-1192. [CrossRef]

6. EFSA Panel on Dietetic Products, Nutrition and Allergies (NDA). Scientific Opinion on the substantiation of health claims related to polyphenols in olive and protection of LDL particles from oxidative damage, maintenance of normal blood HDL-cholesterol concentrations, maintenance of normal blood pressure, "anti-inflammatory properties", "contributes to the upper respiratory tract health", "can help to maintain a normal function of gastrointestinal tract", and "contributes to body defences against external agents" pursuant to Article 13(1) of Regulation (EC) No 1924/20061. EFSA J. 2011, 9, 2033. Available online: www.efsa.europa.eu/efsajournal (accessed on 16 December 2019). [CrossRef]

7. EFSA Panel on Dietetic Products, Nutrition and Allergies (NDA). Scientific Opinion on the substantiation of a health claim related to cocoa flavanols and maintenance of normal endothelium-dependent vasodilation pursuant to Article 13(5) of Regulation (EC) No 1924/2006. EFSA J. 2012, 10, 2809. Available online: www.efsa.europa.eu/efsajournal (accessed on 16 December 2019). [CrossRef]

8. Lekakis, J.; Rallidis, L.S.; Andreadou, I.; Vamvakou, G.; Kazantzoglou, G.; Magiatis, P.; Skaltsounis, A.L.; Kremastinos, D.T. Polyphenolic compounds from red grapes acutely improve endothelial function in patients with coronary heart disease. Eur. J. Cardiovasc. Prev. Rehabil. 2005, 12, 596-600. [CrossRef]

9. Blumberg, J.B.; Vita, J.A.; Chen, C.Y. Concord Grape Juice Polyphenols and Cardiovascular Risk Factors: Dose-Response Relationships. Nutrients 2015, 7, 10032-10052. [CrossRef]

10. Leifert, W.R.; Abeywardena, M.Y. Cardioprotective actions of grape polyphenols. Nutr. Res. 2008, 28, 729-737. [CrossRef]

11. Monagas, M.; Gómez-Cordovés, C.; Bartolomé, B.; Laureano, O.; Ricardo da Silva, J.M. Monomeric, oligomeric and polymeric flavanol composition of wines and grapes from Vitis vinifera L. Cv. Graciano, Tempranillo and Cabernet Sauvignon. J. Agric. Food Chem. 2003, 51, 6475-6481. [CrossRef] [PubMed]

12. Zern, T.L.; Fernandez, M.L. Cardioprotective effects of dietary polyphenols. J. Nutr. 2005, 135, $2291-2294$. [CrossRef] [PubMed]

13. Berman, A.Y.; Motechin, R.A.; Wiesenfeld, M.Y.; Holz, M.K. The therapeutic potential of resveratrol: A review of clinical trials. NPJ Precis. Oncol. 2017, 1, 35. [CrossRef] [PubMed]

14. Rasines-Perea, Z.; Teissedre, P.L. Grape Polyphenols' Effects in Human Cardiovascular Diseases and Diabetes. Molecules 2017, 22, 68. [CrossRef]

15. Georgiev, V.; Ananga, A.; Tsolova, V. Recent advances and uses of grape flavonoids as nutraceuticals. Nutrients 2014, 6, 391-415. [CrossRef]

16. Corredor, Z.; Rodríguez-Ribera, L.; Coll, E.; Montañés, R.; Diaz, J.M.; Ballarin, J.; Marcos, R.; Pastor, S. Unfermented grape juice reduce genomic damage on patients undergoing hemodialysis. Food Chem. Toxicol. 2016, 92, 1-7. [CrossRef]

17. Hokayem, M.; Blond, E.; Vidal, H.; Lambert, K.; Meugnier, E.; Feillet-Coudray, C.; Coudray, C.; Pesenti, S.; Luyton, C.; Lambert-Porcheron, S.; et al. Grape polyphenols prevent induced oxidative stress and insulin resistance in first-degree relatives of type 2 diabetic patients. Diabetes Care 2013, 36, 1454-1461. [CrossRef] 
18. Tomé-Carneiro, J.; Gonzálvez, M.; Larrosa, M.; Yáñez-Gascón, M.J.; García-Almagro, F.J.; Ruiz-Ros, J.A.; García-Conesa, M.T.; Tomás-Barberán, F.A.; Espín, J.C. One-year consumption of a grape nutraceutical containing resveratrol improves the inflammatory and fibrinolytic status of patients in primary prevention of cardiovascular disease. Am. J. Cardiol. 2012, 110, 356-363. [CrossRef]

19. Toscano, L.T.; Tavares, R.L.; Toscano, L.T.; Silva, C.S.; Almeida, A.E.; Biasoto, A.C.; Gonçalves Mda, C.; Silva, A.S. Potential ergogenic activity of grape juice in runners. Appl. Physiol. Nutr. Metab. 2015, 40, 899-906. [CrossRef]

20. Razavi, S.M.; Gholamin, S.; Eskandari, A.; Mohsenian, N.; Ghorbanihaghjo, A.; Delazar, A.; Rashtchizadeh, N.; Keshtkar-Jahromi, M.; Argani, H. Red grape seed extract improves lipid profiles and decreases oxidized low-density lipoprotein in patients with mild hyperlipidemia. J. Med. Food 2013, 16, 255-258. [CrossRef]

21. Keevil, J.G.; Osman, H.E.; Reed, J.D.; Folts, J.D. Grape juice, but not orange juice or grapefruit juice, inhibits human platelet aggregation. J. Nutr. 2000, 130, 53-56. [CrossRef] [PubMed]

22. Freedman, J.E.; Parker, C., 3rd; Li, L.; Perlman, J.A.; Frei, B.; Ivanov, V.; Deak, L.R.; Iafrati, M.D.; Folts, J.D. Select flavonoids and whole juice from purple grapes inhibit platelet function and enhance nitric oxide release. Circulation 2001, 103, 2792-2798. [CrossRef] [PubMed]

23. Chaves, A.A.; Joshi, M.S.; Coyle, C.M.; Brady, J.E.; Dech, S.J.; Schanbacher, B.L.; Baliga, R.; Basuray, A.; Bauer, J.A. Vasoprotective endothelial effects of a standardized grape product in humans. Vascul. Pharmacol. 2009, 50, 20-26. [CrossRef] [PubMed]

24. Li, S.H.; Zhao, P.; Tian, H.B.; Chen, L.H.; Cui, L.Q. Effect of Grape Polyphenols on Blood Pressure: A Meta-Analysis of Randomized Controlled Trials. PLoS ONE 2015, 10, e0137665. [CrossRef] [PubMed]

25. Feringa, H.H.; Laskey, D.A.; Dickson, J.E.; Coleman, C.I. The effect of grape seed extract on cardiovascular risk markers: A meta-analysis of randomized controlled trials. J. Am. Diet. Assoc. 2011, 111, 1173-1181. [CrossRef]

26. Zhang, H.; Liu, S.; Li, L.; Liu, S.; Liu, S.; Mi, J.; Tian, G. The impact of grape seed extract treatment on blood pressure changes: A meta-analysisof 16 randomized controlled trials. Medicine 2016, 95, e4247. [CrossRef]

27. Sivaprakasapillai, B.; Edirisinghe, I.; Randolph, J.; Steinberg, F.; Kappagoda, T. Effect of grape seed extract on blood pressure in subjects with the metabolic syndrome. Metabolism 2009, 58, 1743-1746. [CrossRef]

28. Zhu, X.; Wu, C.; Qiu, S.; Yuan, X.; Li, L. Effects of resveratrol on glucose control and insulin sensitivity in subjects with type 2 diabetes: Systematic review and meta-analysis. Nutr. Metab. 2017, 14, 60. [CrossRef]

29. Kar, P.; Laight, D.; Rooprai, H.K.; Shaw, K.M.; Cummings, M. Effects of grape seed extract in Type 2 diabetic subjects at high cardiovascular risk: A double blind randomized placebo controlled trial examining metabolic markers, vascular tone, inflammation, oxidative stress and insulin sensitivity. Diabet. Med. 2009, 26, 526-531. [CrossRef]

30. Queipo-Ortuño, M.I.; Boto-Ordóñez, M.; Murri, M.; Gomez-Zumaquero, J.M.; Clemente-Postigo, M.; Estruch, R.; Cardona Diaz, F.; Andrés-Lacueva, C.; Tinahones, F.J. Influence of red wine polyphenols and ethanol on the gut microbiota ecology and biochemical biomarkers. Am. J. Clin. Nutr. 2012, 95, 1323-1334. [CrossRef]

31. Costabile, G.; Vitale, M.; Luongo, D.; Naviglio, D.; Vetrani, C.; Ciciola, P.; Tura, A.; Castello, F.; Mena, P.; Del Rio, D.; et al. Grape pomace polyphenols improve insulin response to a standard meal in healthy individuals: A pilot study. Clin. Nutr. 2018, 7, 2727-2734. [CrossRef] [PubMed]

32. Urquiaga, I.; D’Acuña, S.; Pérez, D.; Dicenta, S.; Echeverría, G.; Rigotti, A.; Leighton, F. Wine grape pomace flour improves blood pressure, fasting glucose and protein damage in humans: A randomized controlled trial. Biol. Res. 2015, 48, 49. [CrossRef] [PubMed]

33. Martínez-Maqueda, D.; Zapatera, B.; Gallego-Narbón, A.; Vaquero, M.P.; Saura-Calixto, F.; Pérez-Jiménez, J. A 6-week supplementation with grape pomace to subjects at cardiometabolic risk ameliorates insulin sensitivity, without affecting other metabolic syndrome markers. Food Funct. 2018, 9, 6010-6019. [CrossRef] [PubMed]

34. Vigna, G.B.; Costantini, F.; Aldini, G.; Carini, M.; Catapano, A.; Schena, F.; Tangerini, A.; Zanca, R.; Bombardelli, E.; Morazzoni, P.; et al. Effect of a standardized grape seed extract on low density lipoprotein susceptibility to oxidation in heavy smokers. Metabolism 2003, 52, 1250-1257. [CrossRef]

35. Preuss, H.G.; Wallerstedt, D.; Talpur, N.; Tutuncuoglu, S.O.; Echard, B.; Myers, A.; Bui, M.; Bagchi, D. Effects of niacin-bound chromium and grape seed proanthocyanidin extract on the lipid profile of hypercholesterolemic subjects: A pilot study. J. Med. 2000, 31, 227-246. [PubMed] 
36. Castilla, P.; Echarri, R.; Dávalos, A.; Cerrato, F.; Ortega, H.; Teruel, J.L.; Lucas, M.F.; Gómez-Coronado, D.; Ortuño, J.; Lasunción, M.A. Concentrated red grape juice exerts antioxidant, hypolipidemic, and antiinflammatory effects in both hemodialysis patients and healthy subjects. Am. J. Clin. Nutr. 2006, 84, 252-262. [CrossRef]

37. Castilla, P.; Davalos, A.; Teruel, J.L.; Cerrato, F.; Fernandez-Lucas, M.; Merino, J.L.; Sánchez-Martín, C.C.; Ortuño, J.; Lasunción, M.A. Comparative effects of dietary supplementation with red grape juice and vitamin E on production of superoxide by circulating neutrophil, N.A.DPH oxidase in hemodialysis patients. Am. J. Clin. Nutr. 2008, 87, 1053-1106. [CrossRef]

38. Sahebkar, A. Effects of resveratrol supplementation on plasma lipids: A systematic review and meta-analysis of randomized controlled trials. Nutr. Rev. 2013, 71, 822-835. [CrossRef]

39. O’Byrne, D.J.; Devaraj, S.; Grundy, S.M.; Jialal, I. Comparison of the antioxidant effects of Concord grape juice flavonoids and alpha-tocopherol on markers of oxidative stress in healthy adults. Am. J. Clin. Nutr. 2002, 76, 1367-1374. [CrossRef]

40. Evans, M.; Wilson, D.; Guthrie, N. A randomized, double-blind, placebo-controlled, pilot study to evaluate the effect of whole grape extract on antioxidant status and lipid profile. J. Funct. Foods 2014, 7, 680-691. [CrossRef]

41. Higgins, J.P.; Thompson, S.G.; Deeks, J.J.; Altman, D.G. Measuring inconsistency in meta-analyses. BMJ 2003, 327, 557-560. [CrossRef] [PubMed]

42. Sterne, J.A.; Egger, M.; Smith, G.D. Systematic reviews in health care: Investigating and dealing with publication and other biases in meta-analysis. BMJ 2001, 323, 101-105. [CrossRef] [PubMed]

43. Duval, S.; Tweedie, R. Trim and fill: A simple funnel-plot-based method of testing and adjusting for publication bias in meta-analysis. Biometrics 2000, 56, 455-463. [CrossRef] [PubMed]

44. Zern, T.L.; Wood, R.J.; Greene, C.; West, K.L.; Liu, Y.; Aggarwal, D.; Shachter, N.S.; Fernandez, M.L. Grape polyphenols exert a cardioprotective effect in pre- and postmenopausal women by lowering plasma lipids and reducing oxidative stress. J. Nutr. 2005, 135, 1911-1917. [CrossRef]

45. Vaisman, N.; Niv, E. Daily consumption of red grape cell powder in a dietary dose improves cardiovascular parameters: A double blind, placebo-controlled, randomized study. Int. J. Food Sci. Nutr. 2015, 66, 342-349. [CrossRef]

46. Sano, A.; Uchida, R.; Saito, M.; Shioya, N.; Komori, Y.; Tho, Y.; Hashizume, N. Beneficial effects of grape seed extract on malondialdehyde-modified, LDL. J. Nutr. Sci. Vitaminol. 2007, 53, 174-182. [CrossRef]

47. Argani, H.; Ghorbanihaghjo, A.; Vatankhahan, H.; Rashtchizadeh, N.; Raeisi, S.; Ilghami, H. The effect of red grape seed extract on serum paraoxonase activity in patients with mild to moderate hyperlipidemia. Sao Paulo Med. J. 2016, 134, 234-239. [CrossRef]

48. Banini, A.E.; Boyd, L.C.; Allen, J.C.; Allen, H.G.; Sauls, D.L. Muscadine grape products intake, diet and blood constituents of non-diabetic and type2 diabetic subjects. Nutrition 2006, 22, 1137-1145. [CrossRef]

49. Dohadwala, M.M.; Hamburg, N.M.; Holbrook, M.; Kim, B.H.; Duess, M.A.; Levit, A.; Titas, M.; Chung, W.B.; Vincent, F.B.; Caiano, T.L.; et al. Effects of Concord grape juice on ambulatory blood pressure in prehypertension and stage 1 hypertension. Am. J. Clin. Nutr. 2010, 92, 1052-1059. [CrossRef]

50. Han, H.J.; Jung, U.J.; Kim, H.J.; Cho, S.J.; Kim, A.H.; Han, Y.; Choi, M.S. Combined Supplementation with Grape Pomace and Omija Fruit Ethanol Extracts Dose-Dependently Improves Body Composition, Plasma Lipid Profiles, Inflammatory Status, and Antioxidant Capacity in Overweight and Obese Subjects. J. Med. Food 2016, 19, 170-180. [CrossRef]

51. Hansen, A.S.; Marckmann, P.; Dragsted, L.O.; Finné Nielsen, I.L.; Nielsen, S.E.; Grønbaek, M. Effect of red wine and red grape extract on blood lipids, haemostatic factors, and other risk factors for cardiovascular disease. Eur. J. Clin. Nutr. 2005, 59, 449-455. [CrossRef] [PubMed]

52. Hollis, J.H.; Houchins, J.A.; Blumberg, J.B.; Mattes, R.D. Effects of concord grape juice on appetite, diet, body weight, lipid profile, and antioxidant status of adults. J. Am. Coll. Nutr. 2009, 28, 574-582. [CrossRef]

53. Jiménez, J.P.; Serrano, J.; Tabernero, M.; Arranz, S.; Díaz-Rubio, M.E.; García-Diz, L.; Goñi, I.; Saura-Calixto, F. Effects of grape antioxidant dietary fiber in cardiovascular disease risk factors. Nutrition 2008, 24, 646-653. [CrossRef]

54. Mellen, P.B.; Daniel, K.R.; Brosnihan, K.B.; Hansen, K.J.; Herrington, D.M. Effect of muscadine grape seed supplementation on vascular function in subjects with or at risk for cardiovascular disease: A randomized crossover trial. J. Am. Coll. Nutr. 2010, 29, 469-475. [CrossRef] [PubMed] 
55. Millar, C.L.; Duclos, Q.; Garcia, C.; Norris, G.H.; Lemos, B.S.; DiMarco, D.M.; Fernandez, M.L.; Blesso, C.N. Effects of Freeze-Dried Grape Powder on High-Density Lipoprotein Function in Adults with Metabolic Syndrome: A Randomized Controlled Pilot Study. Metab. Syndr. Relat. Disord. 2018, 16, 464-469. [CrossRef] [PubMed]

56. Park, Y.K.; Lee, S.H.; Park, E.; Kim, J.S.; Kang, M.H. Changes in antioxidant status, blood pressure, and lymphocyte DNA damage from grape juice supplementation. Ann. N. Y. Acad. Sci. 2009, 1171, 385-390. [CrossRef] [PubMed]

57. Siasos, G.; Tousoulis, D.; Kokkou, E.; Oikonomou, E.; Kollia, M.E.; Verveniotis, A.; Gouliopoulos, N.; Zisimos, K.; Plastiras, A.; Maniatis, K.; et al. Favorable effects of concord grape juice on endothelial function and arterial stiffness in healthy smokers. Am. J. Hypertens. 2014, 27, 38-45. [CrossRef] [PubMed]

58. Taghizadeh, M.; Malekian, E.; Memarzadeh, M.R.; Mohammadi, A.A.; Asemi, Z. Grape Seed Extract Supplementation and the Effects on the Biomarkers of OxidativeStress and Metabolic Profiles in Female Volleyball Players: A Randomized, Double-Blind, Placebo-Controlled Clinical Trial. Iran. Red Crescent Med. J. 2016, 18, e31314. [CrossRef]

59. Tomé-Carneiro, J.; Gonzálvez, M.; Larrosa, M.; García-Almagro, F.J.; Avilés-Plaza, F.; Parra, S.; Yáñez-Gascón, M.J.; Ruiz-Ros, J.A.; García-Conesa, M.T.; Tomás-Barberán, F.A.; et al. Consumption of a grape extract supplement containing resveratrol decreases oxidized LDL and ApoB in patients undergoing primary prevention of cardiovascular disease: A triple-blind, 6-month follow-up, placebo-controlled, randomized trial. Mol. Nutr. Food Res. 2012, 56, 810-821. [CrossRef]

60. Yubero, N.; Sanz-Buenhombre, M.; Guadarrama, A.; Villanueva, S.; Carrión, J.M.; Larrarte, E.; Moro, C. LDL cholesterol-lowering effects of grape extract used as a dietary supplement on healthy volunteers. Int. J. Food Sci. Nutr. 2013, 64, 400-406. [CrossRef]

61. Zunino, S.J.; Peerson, J.M.; Freytag, T.L.; Breksa, A.P.; Bonnel, E.L.; Woodhouse, L.R.; Storms, D.H. Dietary grape powder increases IL-1 $\beta$ and IL-6 production by lipopolysaccharide-activated monocytes and reduces plasma concentrations of large LDL and large LDL-cholesterol particles in obese humans. Br. J. Nutr. 2014, 112, 369-380. [CrossRef] [PubMed]

62. Wilson, P.W.; Anderson, K.M.; Castelli, W.P. Twelve-year incidence of coronary heart disease in middle-aged adults during the era of hypertensive therapy: The Framingham offspring study. Am. J. Med. 1991, 90, 11-16. [CrossRef]

63. Woerdeman, J.; van Poelgeest, E.; Ket, J.C.F.; Eringa, E.C.; Serné, E.H.; Smulders, Y.M. Do grape polyphenols improve metabolic syndrome components? A systematic review. Eur. J. Clin. Nutr. 2017, 71, 1381-1392. [CrossRef] [PubMed]

64. Buchholz, T.; Melzig, M.F. Polyphenolic Compounds as Pancreatic Lipase Inhibitors. Planta Med. 2015, 81, 771-783. [CrossRef] [PubMed]

65. Zern, T.L.; West, K.L.; Fernandez, M.L. Grape polyphenols decrease plasma triglycerides and cholesterol accumulation in the aorta of ovariectomized guinea pigs. J. Nutr. 2003, 133, 2268-2272. [CrossRef]

66. Qin, Y.; Xia, M.; Ma, J.; Hao, Y.; Liu, J.; Mou, H.; Cao, L.; Ling, W. Anthocyanin supplementation improves serum LDL- and HDL-cholesterol concentrations associated with the inhibition of cholesteryl ester transfer protein in dyslipidemic subjects. Am. J. Clin. Nutr. 2009, 90, 485-492. [CrossRef]

67. Hirano, R.; Sasamoto, W.; Matsumoto, A.; Itakura, H.; Igarashi, O.; Kondo, K. Antioxidant ability of various flavonoids against DPPH radicals and LDL oxidation. J. Nutr. Sci. Vitaminol. 2001, 47, 357-362. [CrossRef]

68. Toaldo, I.M.; Cruz, F.A.; Alves Tde, L.; de Gois, J.S.; Borges, D.L.; Cunha, H.P.; da Silva, E.L.; Bordignon-Luiz, M.T. Bioactive potential of Vitis labrusca, L. Grape juices from the Southern Region of Brazil: Phenolic and elemental composition and effect on lipid peroxidation in healthy subjects. Food Chem. 2015, 173, 527-535. [CrossRef]

69. Xia, E.-Q.; Deng, G.-F.; Guo, Y.-J.; Li, H.-B. Biological Activities of Polyphenols from Grapes. Int. J. Mol. Sci. 2010, 11, 622-646. [CrossRef]

70. Banach, M.; Patti, A.M.; Giglio, R.V.; Cicero, A.F.G.; Atanasov, A.G.; Bajraktari, G.; Bruckert, E.; Descamps, O.; Djuric, D.M.; Ezhov, M.; et al. International Lipid Expert Panel (ILEP). The Role of Nutraceuticals in Statin Intolerant Patients. J. Am. Coll. Cardiol. 2018, 72, 96-118. [CrossRef] 
71. Cicero, A.F.G.; Colletti, A.; Bajraktari, G.; Descamps, O.; Djuric, D.M.; Ezhov, M.; Fras, Z.; Katsiki, N.; Langlois, M.; Latkovskis, G.; et al. Lipid-lowering nutraceuticals in clinical practice: Position paper from an International Lipid Expert Panel. Nutr. Rev. 2017, 75, 731-767. [CrossRef] [PubMed]

72. Wightman, J.D.; Heuberger, R.A. Effect of grape and other berries on cardiovascular health. J. Sci. Food Agric. 2015, 95, 1584-1597. [CrossRef] [PubMed]

(C) 2020 by the authors. Licensee MDPI, Basel, Switzerland. This article is an open access article distributed under the terms and conditions of the Creative Commons Attribution (CC BY) license (http://creativecommons.org/licenses/by/4.0/). 